\title{
Antecedents of Psychological Empowerment and The Impact on Nurses Burnout
}

\author{
Jason Jason* ${ }^{\star}$, Ferdi Antonio \\ School of Management, School of Medicine, Pelita Harapan University, Jakarta, \\ Indonesia
}

\section{G open access}

\section{Jurnal Keperawatan Padjadjaran (JKP)}

Volume 9(2), 148-158 (C) The Author(s) 2021 http://dx.doi.org/10.24198/jkp. v9i2.1674

\section{Article Info}

Received : June 29, 2021

Revised : August 27, 2021

Accepted : August 29, 2021

Published : August 31, 2021

Corresponding author

Jason Jason

School of Management, School of Medicine, Pelita Harapan University, Jakarta, Indonesia, Postal address: 15811, E-mail: jasonbustam@gmail.com

\section{Citation}

Jason, J., \& Antonio, F. (2021). Antecedents of Psychological Empowerment and The Impact on Nurses Burnout. Jurnal Keperawatan Padjadjaran, 9(2), 148-158. https://doi.org/10.24198/ jkp.v9i2.1674

\section{Website}

http://jkp.fkep.unpad.ac.id/index. php/jkp

This is an Open Access article distributed under the terms of the Creative Commons Attribution-NonCommercial 4.0 International License.

\begin{abstract}
Background: The health and well-being of nurses are deteriorating due to several factors such as complicated nursing practices, high patient demands, heavy workload, all of which result in frustration and lead to burnout, especially emotional exhaustion.

Purpose: The purpose of this study was to examine the effect of the antecedents of psychological empowerment on burnout in nurses who worked at the COVID-19 Hospital XYZ in Tangerang during the pandemic.

Methods: This research is a quantitative research with survey. PLS-SEM was used to analyse empirical data obtained through simple random sampling. There were 80 samples collected and analysed through questionnaire that had been distributed online. The results showed that six of the eight variables of quality of work life, as well as psychological empowerment mediating variables, had a significant negative effect on burnout (t-statistic > 1.645).

Results: The direct influence on psychological empowerment was found to be the strongest from the opportunity to develop human capital and adequate and fair compensation (coefficient: 0.627 and 0.361 ). It was found that there was a negative impact of psychological empowerment on burnout $(-0.756)$, thus the results of this study support the theory that the quality of work life can increase psychological empowerment among nurses, as well as show a new application to the psychological empowerment of nurses.

Conclusion: This research model has moderate predictive accuracy and medium predictive relevance, so it can be developed in further research. There are managerial implications obtained from the findings of this study related to duration of work per week, work environment, granting of autonomy, as well as recommendations for future researchers regarding sample size and geographic coverage.
\end{abstract}

Keywords: burnout; COVID-19 pandemic; nurse; psychological empowerment; quality of work life.

\section{Introduction}

In December 2019, an infection of unknown cause began in Wuhan, China causing tremendous attention (Catton, 2020). WHO experts confirmed that the pathogen is SARS-CoV-2, and the disease is called Coronavirus Disease 2019 or COVID-19 (Pan et al., 2020). The main route of transmission of the virus is through respiratory droplets and close contact, which makes nurses and doctors a high-risk population. Based on WHO-China expert team report, 2055 healthcare workers, consisting of 476 different hospitals, are suffered from Covid-19 (Liu et al., 2020). The number of patients continues to increase over time, this makes nurses and doctors must face an extraordinary workload and a high risk of exposure to infection, which leads to mental health problems such as anxiety and depression (Kang et al., 2020). Research shows that efforts to maintain the mental health of doctors and nurses can contribute positively to disease control (Chen et al., 2020). Nursing is a noble profession and plays an important role for health care and services in any countries. Nurses work with patients and doctors in serving patients. The 
role of nurses is very important, and their duties can be said to be innumerable (Khamisa, Peltzer, \& Oldenburg, 2013). Nurses are required to have high physical and emotional resilience to deal with work-related problems so that they can work better (Schaufeli, 2006). During the COVID-19 pandemic, nurses experienced various challenges, namely fatigue, discomfort, anxiety, fear of contracting and stress (Wahyuningsih et al., 2020).

Hospitals currently rely on nurses in service quality because the hospital industry is experiencing intense competition. The quality of hospital services is an important issue in increasing patient satisfaction. Nurses as health care providers who in carrying out their duties continuously make good contact with patients, colleagues, superiors or with other members of the health team. Patients who are satisfied with the services provided are an asset. Therefore, it is necessary to have excellent health workers who can provide maximum service. In competitive conditions like this, hospital management must focus on achieving better things than other hospitals. Therefore, hospital management needs to pay attention to the quality of its workforce and not only from a physical point of view but also from a psychological aspect in order to create better services for patients.

$X Y Z$ Hospital is a private hospital located in Tangerang, Banten Province, Indonesia. XYZ Hospital is a type $C$ hospital and functions to provide services for COVID-19 patients. The types of rooms provided by $X Y Z$ Hospital include intensive care rooms, treatment rooms for class 1, 2 and 3 . The facilities provided by XYZ Hospital are ambulances, diagnostic services, radiology, and laboratories. During the COVID-19 pandemic, XYZ Hospital has only received inpatient services for patients infected with COVID-19 and temporarily closed outpatient services. XYZ Hospital provides COVID-19 examination services such as antigen swab and polymerase chain reaction (PCR) examination. The main reason for choosing $X Y Z$ Hospital as the target of this research is because it is the first private hospital in Tangerang that dedicates itself to being the first COVID-19 referral hospital.

Currently, studies on the COVID-19 epidemic situation are more focused on epidemiological investigations, prevention and control, diagnosis, and treatment. Fewer studies have investigated the mental health problems of clinical medical workers during the COVID-19 epidemic. The health and well-being of nurses are deteriorating due to several factors such as complicated nursing practices, high patient demands, heavy workload, all of which result in frustration and lead to burnout, especially emotional exhaustion (Demerouti, Bakker, Nachreiner, \& Schaufeli, 2000). This study aims to determine the effect of quality of work life on psychological empowerment of nursing staff at $X Y Z$ Hospital in 2021 and how psychological empowerment can affect burnout. Improvement for this condition in the future depends on the management of the hospital in determining the cause of burnout and providing the necessary working conditions to reduce the risk of burnout on nurses in the future.

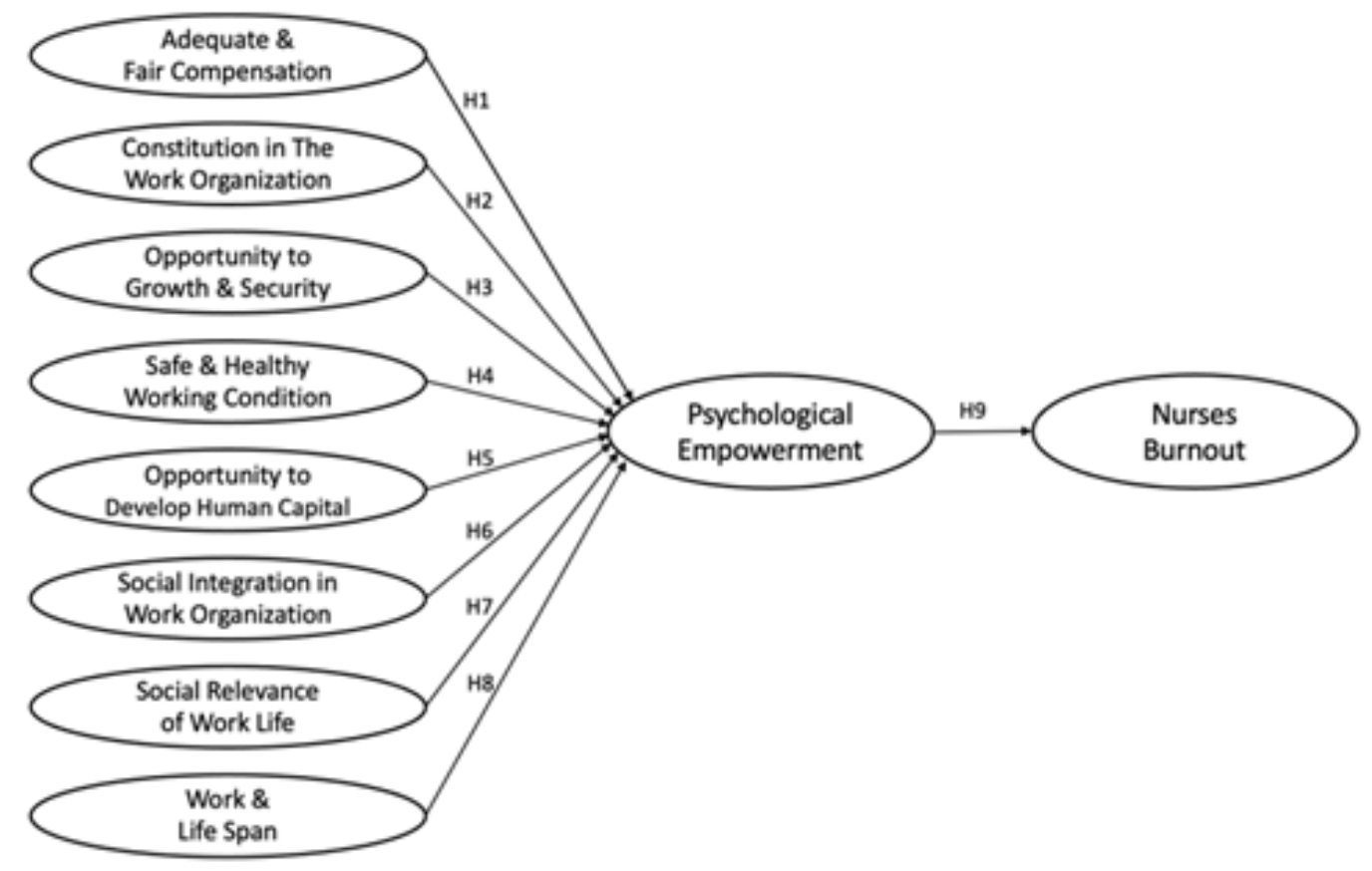

Figure 1. Research Model

Source: Permarupan et al. (2020) 
Table 1. Conceptual Definition and Variable Operationalization

\begin{tabular}{|c|c|c|c|}
\hline Variable & Conceptual Definition & Variable Operationalization & $\begin{array}{c}\text { Source } \\
\text { Scale }\end{array}$ \\
\hline $\begin{array}{l}\text { Adequate and Fair } \\
\text { Compensation } \\
\text { (AFC) }\end{array}$ & $\begin{array}{l}\text { Salaries that meet general } \\
\text { standards and are } \\
\text { sufficient to meet a decent } \\
\text { standard of living, and } \\
\text { have the same ratio as the } \\
\text { salaries earned by others } \\
\text { in similar positions (Kanten } \\
\text { and Sadullah, 2012). }\end{array}$ & $\begin{array}{l}\text { 1. I feel that the salary (remuneration) I get is } \\
\text { reasonable. } \\
2 \text {. I am satisfied with my salary compared to the } \\
\text { salary of my colleagues. } \\
\text { 3. I feel that the bonuses/awards I have received } \\
\text { (example: COVID incentives) from the hospital } \\
\text { where I work have gone well. } \\
\text { 4. I feel that the additional benefits (e.g., education, } \\
\text { courses, CME) from the hospital where I work are } \\
\text { good. }\end{array}$ & $\begin{array}{l}\text { Walton } \\
\text { (1975) } \\
\text { Likert } \\
\text { Scale (1 } \\
\text { to 5) }\end{array}$ \\
\hline $\begin{array}{l}\text { Constitutionalism in } \\
\text { Work }(\mathrm{CW})\end{array}$ & $\begin{array}{l}\text { The rights possessed by } \\
\text { employees and how they } \\
\text { can be used to protect } \\
\text { employees (Kanten and } \\
\text { Sadullah, 2012). }\end{array}$ & $\begin{array}{l}\text { 1. I feel that the efforts of the hospital where I work } \\
\text { in respecting workers' rights are appropriate. } \\
\text { 2. I feel that the freedom of expression (opportunity } \\
\text { to express opinions) is going well in the hospital } \\
\text { where I work. } \\
\text { 3. I feel that the norms and rules that apply in the } \\
\text { hospital where I work are reasonable. } \\
\text { 4. I feel that the treatment by the hospital where I } \\
\text { work for the characteristics and peculiarities of each } \\
\text { individual worker is appropriate. }\end{array}$ & $\begin{array}{l}\text { Walton } \\
\text { (1975) } \\
\text { Likert } \\
\text { Scale (1 } \\
\text { to 5) }\end{array}$ \\
\hline $\begin{array}{l}\text { Opportunity to } \\
\text { Grow and Security } \\
\text { (OW) }\end{array}$ & $\begin{array}{l}\text { Availability of opportunities } \\
\text { for advancement in the } \\
\text { organization or career, } \\
\text { and security of status or } \\
\text { income related to work } \\
\text { (Walton, 1975). }\end{array}$ & $\begin{array}{l}\text { 1. I feel that the opportunities for growth in the } \\
\text { hospital are good at this time. } \\
2 . \text { I feel that the training provided by the hospital } \\
\text { where I work is going well. } \\
\text { 3. I feel that it is natural for workers to submit } \\
\text { resignations at the hospital where I work. } \\
\text { 4. I feel that the support or opportunity provided by } \\
\text { the hospital to study/continue education is going } \\
\text { well. }\end{array}$ & $\begin{array}{l}\text { Walton } \\
\text { (1975) } \\
\text { Likert } \\
\text { Scale (1 } \\
\text { to 5) }\end{array}$ \\
\hline $\begin{array}{l}\text { Safe and Healthy } \\
\text { Working Conditions } \\
\text { (WC) }\end{array}$ & $\begin{array}{l}\text { A safe and healthy } \\
\text { environment for employees } \\
\text { related to comfort in terms } \\
\text { of physical and health } \\
\text { (Kanten and Sadullah, } \\
\text { 2012). }\end{array}$ & $\begin{array}{l}\text { 1. I feel the weekly working hours (number of hours } \\
\text { worked/shift) of my job are reasonable. } \\
\text { 2. I feel my current workload is reasonable. } \\
\text { 3. I feel that the use of technology in my work is } \\
\text { going well. } \\
\text { 4. I feel that the health in the hospital where I work } \\
\text { (example: cleanliness) is decent. } \\
\text { 5. I feel that the safety equipment, PPE, and } \\
\text { protection provided by the hospital are adequate. } \\
6 . \text { I feel that the fatigue caused by my job is normal. }\end{array}$ & $\begin{array}{l}\text { Walton } \\
\text { (1975) } \\
\text { Likert } \\
\text { Scale (1 } \\
\text { to 5) }\end{array}$ \\
\hline $\begin{array}{l}\text { Opportunity to } \\
\text { Develop Human } \\
\text { Capital (UCW) }\end{array}$ & $\begin{array}{l}\text { Human capacity } \\
\text { development which } \\
\text { shows the provision of } \\
\text { a work environment that } \\
\text { facilitates workers to get } \\
\text { opportunities and gain } \\
\text { autonomy (Kanten and } \\
\text { Sadullah, 2012). }\end{array}$ & $\begin{array}{l}\text { 1. I feel that the autonomy (opportunity to make } \\
\text { decisions) that I have in the hospital is natural. } \\
2 . \text { I feel the tasks / work / activities that I do are } \\
\text { important. } \\
\text { 3. I feel that it is normal to do several tasks at the } \\
\text { same time. } \\
\text { 4. I feel that the performance appraisal system in } \\
\text { the hospital is running well. } \\
5 . \text { I feel the responsibility given to me is reasonable. }\end{array}$ & $\begin{array}{l}\text { Walton } \\
(1975) \\
\text { Likert } \\
\text { Scale (1 } \\
\text { to 5) }\end{array}$ \\
\hline
\end{tabular}

\section{Methods}

This research is a cross-sectional, quantitative study with hypothesis testing, correlational, non-causation design, and also non-interventional study which means that there are no interventions assigned. The research focused on XYZ Hospital in Tangerang,
Banten Province, which is a type $C$ hospital which has served to provide services for COVID-19 patients since the pandemic. Prior to the questionnaire distribution, the hospital management has granted permission to collect data. Based on the theory of quality of work life, it is known that compensation, constitution, opportunities, workplace conditions, 
Continue Table 1. Conceptual Definition and Variable Operationalization

\begin{tabular}{|c|c|c|c|}
\hline Variable & Conceptual Definition & Variable Operationalization & $\begin{array}{c}\text { Source/ } \\
\text { Scale }\end{array}$ \\
\hline $\begin{array}{l}\text { Social Integration at } \\
\text { Work (SIW) }\end{array}$ & $\begin{array}{l}\text { Important component } \\
\text { related to how } \\
\text { employees have the } \\
\text { feeling of ownership of } \\
\text { the company (Kanten } \\
\text { and Sadullah, 2012). }\end{array}$ & $\begin{array}{l}\text { 1. I feel that the treatment for social, racial, religious, } \\
\text { gender, and others in the hospital where I work is } \\
\text { appropriate. } \\
\text { 2. I feel that my relationship with co-workers and } \\
\text { superiors is going well. } \\
\text { 3. I feel that the commitments made by my team and } \\
\text { colleagues have gone well. } \\
\text { 4. I feel that the acceptance or appreciation given } \\
\text { to me when conveying ideas and initiatives is } \\
\text { appropriate. }\end{array}$ & $\begin{array}{l}\text { Walton } \\
\text { (1975) } \\
\text { Likert } \\
\text { Scale (1 } \\
\text { to 5) } \\
\text {. }\end{array}$ \\
\hline $\begin{array}{l}\text { Social Relevance } \\
\text { and Importance of } \\
\text { Work (SRI) }\end{array}$ & $\begin{array}{l}\text { The attitude of } \\
\text { responsibility given } \\
\text { by the company in } \\
\text { maintaining the quality } \\
\text { of working conditions } \\
\text { socially (Kanten and } \\
\text { Sadullah, 2012). }\end{array}$ & $\begin{array}{l}\text { 1. I feel proud of the work I do. } \\
2 . \text { I feel that the image of the hospital in the community } \\
\text { is good. } \\
\text { 3. I feel that the contribution of the hospital where I } \\
\text { work to the community is good. } \\
4 \text {. I feel that the services provided by the hospital } \\
\text { where I work are reasonable. } \\
5 . \text { I feel that the way employees are treated at the } \\
\text { hospital where I work is appropriate. }\end{array}$ & $\begin{array}{l}\text { Walton } \\
(1975) \\
\text { Likert } \\
\text { Scale (1 } \\
\text { to 5) }\end{array}$ \\
\hline $\begin{array}{l}\text { Work and Life Span } \\
\text { (OSW) }\end{array}$ & $\begin{array}{l}\text { The balance of a } \\
\text { person's work role with } \\
\text { their life (Walton, 1975). }\end{array}$ & $\begin{array}{l}\text { 1. I feel the influence of my work on my family and } \\
\text { routine are reasonable. } \\
2 \text {. I feel the influence of my work on my free time is } \\
\text { reasonable. } \\
3 . \text { I feel that the division of my work schedule and rest } \\
\text { time is good. }\end{array}$ & $\begin{array}{l}\text { Walton } \\
\text { (1975) } \\
\text { Likert } \\
\text { Scale (1 } \\
\text { to 5) }\end{array}$ \\
\hline $\begin{array}{l}\text { Psychological } \\
\text { Empowerment (PE) }\end{array}$ & $\begin{array}{l}\text { Employees' perceptions } \\
\text { of control over their } \\
\text { work environment and } \\
\text { congruence between } \\
\text { values and beliefs } \\
\text { related to their work, and } \\
\text { those of their employers } \\
\text { (Spreitzer, 1995). }\end{array}$ & $\begin{array}{l}\text { 1. The work I do is important to me. } \\
\text { 2. My work activities are meaningful to me personally. } \\
\text { 3. The work I do is valuable to me. } \\
\text { 4. I believe that I could do my job. } \\
\text { 5. I feel confident in my ability to carry out my work } \\
\text { activities. } \\
\text { 6. I have mastered the skills required for my job. } \\
\text { 7. I have autonomy in determining how I do my job. } \\
\text { 8. I can decide for myself how to do things related to } \\
\text { my work. } \\
\text { 9. I have ample opportunities to carry out my work- } \\
\text { related activities independently. } \\
\text { 10. I have a big impact on the hospital where I work. } \\
\text { 11. I have a lot of control/control over what happens at } \\
\text { the hospital where I work. } \\
\text { 12. I have a significant influence over what happens at } \\
\text { the hospital where I work. }\end{array}$ & $\begin{array}{l}\text { Spreitzer } \\
(1995) \\
\text { Likert } \\
\text { Scale (1 } \\
\text { to } 5)\end{array}$ \\
\hline
\end{tabular}

working period and integration and social relevance of the workplace play an important role. The quality of work life component affects the psychological empowerment of employees (Salimi \& Saeidian, 2015). Informed consent was obtained from the respondents and ethical clearance was not required in the process of this study.

In this research model, the psychological empowerment variable is tested for its impact on burnout as the dependent variable of the study. This study uses a research model that has been carried out by previous researchers (Permarupan et al., 2020), which tested empirically on nurses who provide services to patients with suspected or confirmed COVID-19 at XYZ Hospital in Tangerang. The objects in this study are all variables included in this research model. The dependent variable of this research is burnout, while psychological empowerment is a mediating variable. Data obtained from individuals are considered as the unit of analysis of the study. The respondent's two mandatory criteria must be met: first, the respondent is a full-time nurse, second, the respondent performs care or services for COVID-19 patients. The reason for choosing nurses as the unit of analysis is because nurses have more time to interact with COVID-19 
Continue Table 1. Conceptual Definition and Variable Operationalization

\begin{tabular}{|c|c|c|c|}
\hline Variable & Conceptual Definition & Vaariable Operationalization & $\begin{array}{c}\text { Sourcel } \\
\text { Scale }\end{array}$ \\
\hline Burnout (NB) & $\begin{array}{l}\text { Emotional exhaustion } \\
\text { syndrome that is common } \\
\text { among individuals } \\
\text { characterized by increased } \\
\text { feelings of emotional } \\
\text { exhaustion (Maslach \& } \\
\text { Jackson, 1981). }\end{array}$ & $\begin{array}{l}\text { 1. I feel emotionally drained as a result of my job. } \\
\text { 2. I feel tired at the end of my shift. } \\
\text { 3. I feel tired when I wake up in the morning and } \\
\text { must face the same work. } \\
\text { 4. Working with the people in this hospital all day is } \\
\text { a burden for me. } \\
\text { 5. I often feel frustrated with my work. } \\
\text { 6. I have a hard time understanding how my } \\
\text { patients feel. } \\
\text { 7. I feel I am handling patient problems } \\
\text { ineffectively. } \\
\text { 8. I feel low on energy when I am on duty. } \\
\text { 9. I feel depressed after working with patients. } \\
\text { 10. I feel I treat my patients as if they were just } \\
\text { 'objects'. } \\
\text { 11. I have become more insensitive to people } \\
\text { since I worked during the COVID-19 pandemic. } \\
\text { 12. I don't really care about the patient's feelings. } \\
\text { 13. I feel that patients often blame me for their } \\
\text { complaints. }\end{array}$ & $\begin{array}{l}\text { Maslach } \\
\text { (1981) } \\
\text { Likert } \\
\text { Scale (1 } \\
\text { to 5) }\end{array}$ \\
\hline
\end{tabular}

patients than other health workers, and because there are not many studies using this type of respondent during the COVID-19 pandemic period. This study used an ordinal scale to determine the differences between each construct and facilitate the conversion of data obtained from questionnaire using a Likert scale into numeric form.

The population of this study are all full-time nurses who work at XYZ Hospital and provide services to patients suspected of or confirmed COVID-19 at XYZ Hospital in Tangerang in 2021. The samples in this study are nurses who work full time at XYZ Hospital and provide services or have a close contact with a patient suspected of being infected with the COVID-19 virus. Sampling was carried out in March - April 2021 in conditions of the COVID-19 pandemic. To calculate the number of samples needed in a known population, this study used the calculation method of Krejcie and Morgan (1970). The research sample that meets the requirements is a total of 80 respondents. The sampling method of this research is simple random sampling. Respondents who have met the initial criteria will be sent a link to a questionnaire that can be filled out online. This research data analysis method uses multivariate analysis because of the complexity of the research model and the use of latent variables or constructs (Sekaran \& Bougie, 2016).

There are ten variables with nine paths and there is one mediating variable. Therefore, we need a method that can test the effect between variables simultaneously to the dependent variable. Researchers use the PLS-SEM analysis method because the structural model is complex and includes many indicators and model relationships and is theory development in exploratory research and can provide explanation and predictive abilities for further development (Hair et al., 2019). There are two types of models produced by PLS-SEM analysis, namely the outer model and the inner model. The outer model or measurement model examines the relationship between indicators and construct variables, which includes two parts, namely reliability testing and validity testing. The reliability testing phase includes indicator reliability (outer loading), and construct reliability (Cronbach's alpha and composite reliability). The validity testing phase includes construct validity (average variance extracted) and discriminant validity (heterotraitmonotrait ratio). If these four things have met the requirements of reliability and validity, it can proceed to the next stage.

Next is the inner model or structural model that provides the relationship between the constructs in the research model, assesses the quality of the model and tests the significance of the effect and coefficient analysis. The first step of this model is multicollinearity testing, based on the value of the variance inflation factor (VIF). The second step is to determine the explanatory and predictive abilities of the research model using the determinant coefficient or R2 which ranges between 0 and 1 where higher results indicate higher accuracies and predictions. These results can be divided into three levels, namely $0.75,0.5$ and 0.25 or called substantial, moderate, and weak (Hair et al., 2019). The third is the assessment of the predictive ability of a model if there is a change in the data with Q2 or predictive relevance. A Q2 predict value that is more than zero indicates that the model has a good prediction if there is a change in data during its analysis. On the other hand, a Q2 predict value that is less than zero indicates that the model has no relevant predictions.

The next stage is the stage of testing the hypothesis obtained from the bootstrapping or 
resampling menu on SmartPLS. This is done by looking at two assessments. The first assessment is the significance of the relationship between variables using the T-table value with T-statistics. If the T-statistic has a higher value than the T-table, then the effect of the variable is declared significant. On the other hand, if the T-statistic value has a lower value than the T-table, then the effect of the variable is declared insignificant. This study uses a significance level of 0.05 , and the degree of freedom is classified as infinity, so the T-table value for the one-tailed test is 1.645 (Beyer, 2017). The second assessment is path analysis to see the strength of the pathway through the mediating variable, and to see the mediating ability of the research mediation variable by looking at the specific indirect effect. The last stage of SmartPLS analysis uses Importance Performance Map Analysis (IPMA) to see the combination of descriptive analysis with inferential analysis. The combination of the two analyses is depicted in a two-axis mapping that shows the position of variables and indicators based on the mean (descriptive analysis) and total effect (inferential analysis) in the figure (Sarstedt, 2017). IPMA can provide a practical overview of what needs to be improved.

\section{Results}

From as many as 80 respondents who have met the research criteria, the profile of respondents are as follows table 2.

The table above shows that the respondents are divided into the ages of 20 to 50 years and from the data it can be assumed that the respondents already have emotional maturity. most respondents have educational background of professional and vocational nursing education which continued with S1 and Diploma. With this background, respondents are considered competent and able to understand the questions in the questionnaire well. For the length of time working as a nurse, various results

Table 2. Respondents Demographic Profile

\begin{tabular}{|c|c|c|c|}
\hline Description & Category & Quantity & $\%$ \\
\hline \multirow[t]{3}{*}{ Employment Status } & Full Timer & 80 & 100 \\
\hline & Part Timer & 0 & 0 \\
\hline & Total & 80 & 100 \\
\hline \multirow[t]{3}{*}{ Gender } & Female & 64 & 80 \\
\hline & Male & 16 & 20 \\
\hline & Total & 80 & 100 \\
\hline \multirow[t]{6}{*}{ Age } & $<20$ & 0 & 0 \\
\hline & $21-30$ & 64 & 80 \\
\hline & $31-40$ & 15 & 18.75 \\
\hline & $41-50$ & 1 & 1.25 \\
\hline & $51-60$ & 0 & 0 \\
\hline & Total & 80 & 100 \\
\hline \multirow[t]{5}{*}{ Last Education } & Highschool & 0 & 0 \\
\hline & Diploma & 12 & 15 \\
\hline & S1 & 25 & 31.25 \\
\hline & Profession & 43 & 53.75 \\
\hline & Total & 80 & 100 \\
\hline \multirow[t]{12}{*}{ Work Experience as Nurse } & $<1$ Year & 11 & 13.75 \\
\hline & $1-2$ Years & 17 & 21.25 \\
\hline & $2-3$ Years & 22 & 27.50 \\
\hline & $3-4$ Years & 8 & 10 \\
\hline & $4-5$ Years & 4 & 5 \\
\hline & $5-6$ Years & 5 & 6.25 \\
\hline & $6-7$ Years & 4 & 5 \\
\hline & $7-8$ Years & 2 & 2.50 \\
\hline & $8-9$ Years & 2 & 2.50 \\
\hline & $9-10$ Years & 2 & 2.50 \\
\hline & $>10$ Years & 3 & 3.75 \\
\hline & Total & 80 & 100 \\
\hline
\end{tabular}


Continue Table 2. Respondents Demographic Profile

\begin{tabular}{llcc}
\hline \multicolumn{1}{c}{ Description } & \multicolumn{1}{c}{ Category } & Quantity & $\%$ \\
\hline Department & Intensive Care Unit & 19 & 23.75 \\
& Regular Ward & 58 & 72.50 \\
& ICU and Regular Ward & 3 & 3.75 \\
& Total & 80 & 100 \\
Work Duration (Per Week) & $35-42$ Hours & 45 & 56.25 \\
& $43-50$ Hours & 35 & 43.75 \\
Previous History of Working in Other Hospital & $>50$ Hours & 0 & 0 \\
& Total & 80 & 100 \\
& Yes & 49 & 61.25 \\
Diagnosed or Confirmed COVID-19 Infection & Never & 31 & 38.75 \\
& Total & 80 & 100 \\
& Yes & 13 & 16.25 \\
& Never & 67 & 83.75 \\
\hline
\end{tabular}

Table 3. Discriminant Validity

\begin{tabular}{|c|c|c|c|c|c|c|c|c|c|c|}
\hline Variable & $\begin{array}{l}\text { Adequate \& Fair } \\
\text { Compensation }\end{array}$ & Burnout & $\begin{array}{l}\text { Constitution } \\
\text { in Work }\end{array}$ & $\begin{array}{l}\text { Opportunity } \\
\text { to Develop } \\
\text { Human } \\
\text { Capital }\end{array}$ & $\begin{array}{l}\text { Opportunity } \\
\text { to grow and } \\
\text { security }\end{array}$ & $\begin{array}{l}\text { Psychological } \\
\text { Empowerment }\end{array}$ & $\begin{array}{c}\text { Safe \& } \\
\text { Healthy } \\
\text { Working } \\
\text { Conditions }\end{array}$ & $\begin{array}{c}\text { Social } \\
\text { Integration } \\
\text { in Work }\end{array}$ & $\begin{array}{l}\text { Social } \\
\text { Relevance } \\
\text { of Work }\end{array}$ & $\begin{array}{c}\text { Work } \\
\text { and } \\
\text { Life } \\
\text { Span }\end{array}$ \\
\hline Burnout & 0.590 & & & & & & & & & \\
\hline $\begin{array}{l}\text { Constitution in } \\
\text { Work }\end{array}$ & 0.751 & 0.493 & & & & & & & & \\
\hline $\begin{array}{l}\text { Opportunity to } \\
\text { Develop Human } \\
\text { Capital }\end{array}$ & 0.794 & 0.480 & 0.819 & & & & & & & \\
\hline $\begin{array}{l}\text { Opportunity } \\
\text { to grow and } \\
\text { security }\end{array}$ & 0.804 & 0.665 & 0.695 & 0.743 & & & & & & \\
\hline $\begin{array}{l}\text { Psychological } \\
\text { empowerment }\end{array}$ & 0.726 & 0.768 & 0.691 & 0.519 & 0.699 & & & & & \\
\hline $\begin{array}{l}\text { Social Integration } \\
\text { in Work }\end{array}$ & 0.755 & 0.635 & 0.813 & 0.800 & 0.775 & 0.734 & 0.822 & & & \\
\hline $\begin{array}{l}\text { Social Relevance } \\
\text { of Work }\end{array}$ & 0.808 & 0.610 & 0.692 & 0.780 & 0.702 & 0.620 & 0.683 & 0.728 & & \\
\hline $\begin{array}{l}\text { Work and Life } \\
\text { Span }\end{array}$ & 0.550 & 0.458 & 0.427 & 0.501 & 0.414 & 0.396 & 0.532 & 0.476 & 0.600 & \\
\hline
\end{tabular}

were found, but mostly the results were two to three years. Most respondents work in regular inpatient wards and some work in intensive care units. This information can provide an overview of the profiles of respondents involved in handling COVID-19 based on the degree of severity. In terms of duration of work, respondents are divided into working with a duration of 35-42 hours per week and 43-50 hours per week. This can affect the level of stress experienced by respondents in terms of workload and duration of work experienced. Hospital management needs to pay attention to the workload experienced by each nurse to create equality, as well as looking at the workforce patterns of nurses. Most of the respondents had worked elsewhere before and some had never worked elsewhere. This may affect the comparison of the quality of work experienced by respondents in the old workplace. Finally, most respondents have never been confirmed with COVID-19 and some of them have been confirmed to be infected with COVID-19. Seeing this, hospital management needs to pay attention to the availability of personal protective equipment (PPE) and the safety of the work environment in order to protect nurses in doing their jobs.

It can be seen from the table above that the results of the discriminant validity test were carried out where the heterotrait-monotrait ratio (HT/MT) of each variable was below 0.9 . It can be concluded that all indicators in this research model have been 
Table 4. Hypothesis Test Results

\begin{tabular}{|c|c|c|c|c|c|}
\hline No. & Path & $\begin{array}{l}\text { Standardized } \\
\text { Coefficient }\end{array}$ & T-statistic & Significance & Result \\
\hline $\mathrm{H} 1$ & $\begin{array}{l}\text { Adequate and Fair } \\
\text { Compensation -> } \\
\text { Psychological Empowerment }\end{array}$ & 0.361 & 2.616 & Significant & $\begin{array}{l}\text { Hypothesis } \\
\text { supported }\end{array}$ \\
\hline $\mathrm{H} 2$ & $\begin{array}{l}\text { Constitution in Work -> } \\
\text { Psychological Empowerment }\end{array}$ & 0.309 & 2.559 & Significant & $\begin{array}{l}\text { Hypothesis } \\
\text { supported }\end{array}$ \\
\hline $\mathrm{H} 3$ & $\begin{array}{l}\text { Opportunity to Grow and } \\
\text { Security } \rightarrow \text { Psychological } \\
\text { Empowerment }\end{array}$ & 0.239 & 2.051 & Significant & $\begin{array}{l}\text { Hypothesis } \\
\text { supported }\end{array}$ \\
\hline $\mathrm{H} 4$ & $\begin{array}{l}\text { Opportunity to Develop } \\
\text { Human Capital -> } \\
\text { Psychological Empowerment }\end{array}$ & 0.627 & 4.657 & Significant & $\begin{array}{l}\text { Hypothesis } \\
\text { supported }\end{array}$ \\
\hline H5 & $\begin{array}{l}\text { Social Integration in Work -> } \\
\text { Psychological Empowerment }\end{array}$ & 0.270 & 1.926 & Significant & $\begin{array}{l}\text { Hypothesis } \\
\text { supported }\end{array}$ \\
\hline $\mathrm{H} 6$ & $\begin{array}{l}\text { Social Relevance in Work -> } \\
\text { Psychological Empowerment }\end{array}$ & 0.102 & 0.792 & Not Significant & $\begin{array}{l}\text { Hypothesis not } \\
\text { supported }\end{array}$ \\
\hline $\mathrm{H} 7$ & $\begin{array}{l}\text { Safe and Healthy Working } \\
\text { Conditions -> Psychological } \\
\text { Empowerment }\end{array}$ & 0.236 & 1.974 & Significant & $\begin{array}{l}\text { Hypothesis } \\
\text { supported }\end{array}$ \\
\hline $\mathrm{H} 8$ & $\begin{array}{l}\text { Work and Life Span -> } \\
\text { Psychological Empowerment }\end{array}$ & 0.030 & 0.352 & Not Significant & $\begin{array}{l}\text { Hypothesis not } \\
\text { supported }\end{array}$ \\
\hline $\mathrm{H} 9$ & $\begin{array}{l}\text { Psychological Empowerment } \\
\rightarrow>\text { Burnout }\end{array}$ & -0.756 & 12.679 & Significant & $\begin{array}{l}\text { Hypothesis } \\
\text { supported }\end{array}$ \\
\hline
\end{tabular}

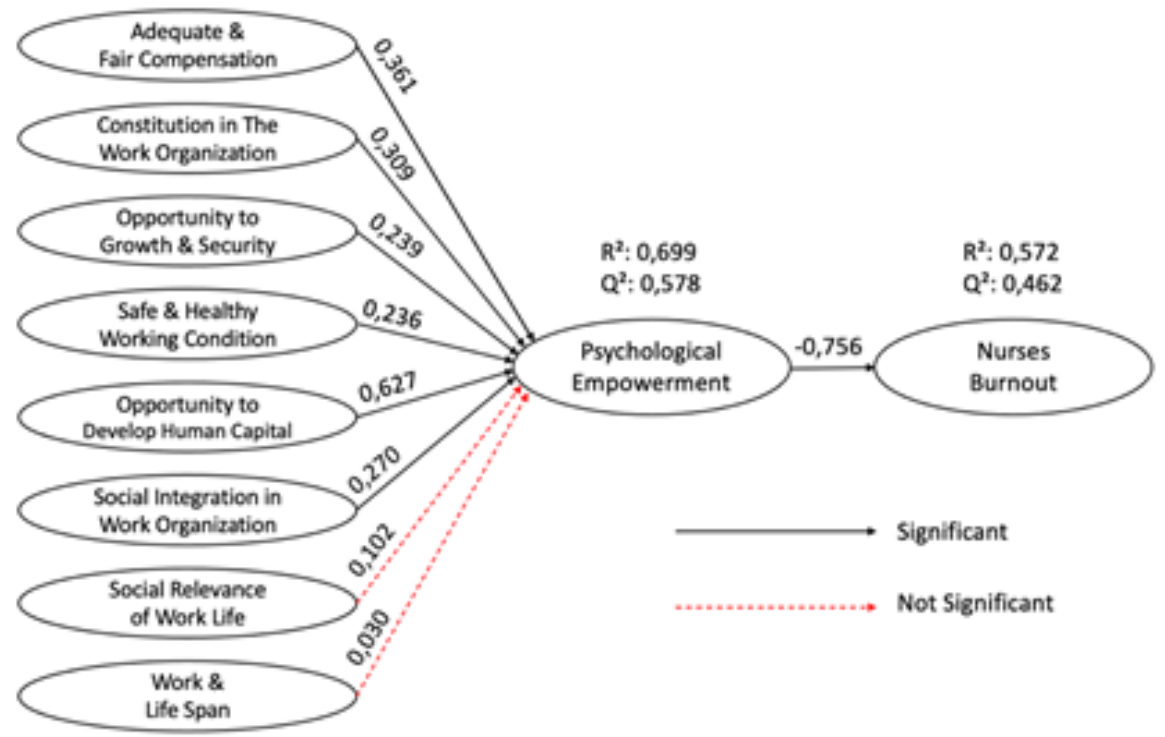

Figure 2. Empirical Model

well discriminated against and can measure their respective constructs. Each indicator can accurately and specifically measure its construct. There are four parameters of reliability and validity testing of the outer model above, namely the reliability indicator (outer loading), construct reliability (Cronbach's alpha and composite reliability), construct validity (average variance extracted), and discriminant validity (heterotrait-monotrait ratio). The model of this study has reliable and valid indicators to measure each construct specifically and can proceed to the next analysis stage, namely the inner model test (structural model). The next stage is a significance test on nine paths to see whether the significance of the influence between variables in the model can be generalized at the population level. For this reason, bootstrapping is carried out by re-sampling on SmartPLS.

The table of hypothesis test results above shows that of the nine hypotheses in the research model tested, seven hypotheses were proven to be significant and have a direction in accordance with 
the direction of the proposed hypothesis, so it can be said that the seven hypotheses are supported. However, two hypotheses were not supported since they were not significant although having the same direction. The description for each hypothesis can be described by the following model figure 2 .

\section{Discussion}

It is known that from the nine paths tested, seven of them were proven to be significant and have influences on accordance with the direction of the hypothesis so that it can be said that the hypothesis is supported, while two of them are not significant so that it can be said that the hypothesis is not supported. This research model can be applied and tested on a wider population based on its geographical coverage. Structural model analysis gives the result that this research model has moderate predictive accuracy and medium predictive relevance on the dependent variable of burnout and the mediating variable of psychological empowerment. Therefore, this research model can be further developed with a larger sample size and apply more rigorous respondent criteria to obtain more predictive results.

The six independent variables in this model have significant influences with the strongest one being derived from the opportunity to develop human capital on psychological empowerment (0.627). Furthermore, the results of the analysis of specific indirect effects also show that the path that has the greatest influence from the independent variable to burnout also comes from the opportunity to develop human capital. Walton (1975) explains that the opportunity to develop human capital is part of the factors thatare relevant to the development ofworkers' abilities, such as: granting certain autonomy, the use of skills from workers, knowledge of the ongoing process to carry out tasks and having a prior plan. Factors related to autonomy and the feasibility of assigning assignments and performance appraisals are very important for nurses who work in hospitals, so hospital management needs to prioritize this. This performance is also relevant to the conditions of the COVID-19 pandemic where the workload given is different from usual and the performance assessment is also different in hospitals. Other studies support that workload is significantly associated with nurse burnout, where high workload increase burnout risk in nurse (Ramdan \& Fadly, 2016). These results are also supported by other studies which state that giving job autonomy, psychological empowerment and justice to workers will increase their commitment and ultimately their turnover intention will be lowered. This will help the organization to retain the workforce. Psychologically empowered individuals have a higher sense of ability, control, and competence (Butt et al., 2017).

The second variable that is no less important is adequate and fair compensation (0.361). This finding is in line with other studies which say that adequate compensation for workers has a positive effect on workers' job and their psychological condition (Khamisa et al., 2013). Adequate and fair compensation is the salary earned by employees to meet the generally accepted standard of salary and is sufficient to meet a level of living that is said to be decent and has the same ratio as the salary received by other people in the same position (Kanten \& Sadullah, 2012). Factors related to salary and incentives or awards are the second most important thing that nurses pay attention to in hospitals.

Other findings from this study also show the importance of the variables studied and show significant results to be prioritized by hospital management to improve nurse performance. The mediating variable used, namely psychological empowerment, has been shown to have a significant effect in reducing the occurrence of burnout and is able to mediate the effect of independent variables and these findings are in line with previous research related to quality of work life and psychological empowerment on burnout in nurses (Permarupan et al., 2020). These results are also supported by other studies which state that psychological empowerment can reduce stress and bring positive changes to the nurse's work environment (Maslach \& Leiter, 2016). Psychological empowerment is a state of mind associated with developing perceptions in the workplace and providing the necessary energy for individuals to perform at their full capacity for organizational well-being (Spreitzer, 2008). Nurses want to grant an autonomy to make decisions and get a reasonable workload with proper compensations. Such situation should be facilitated to prevent burnout or fatigues among nurses which could hamper many services in hospital. Burnout refers to a mental state that develops over a certain period in a work environment with constant stress related to the demands of the job.

\section{Conclusion}

Seven out of nine hypotheses were proven to be supported with significant and appropriate direction of influence. This research model has moderate predictive accuracy and medium predictive relevance on the burnout dependent variable. Therefore, this research is feasible to be conducted, thus required further research development. Based on the results of the study, the opportunity in developing human capital has a strong influence on the psychological empowerment of nurses. This is related to providing a work environment that facilitates nurses to get opportunities and proper autonomy. Therefore, hospital management needs to pay more attention to this matter. Hospitals need to provide equal opportunities for each nurse, as well as giving them the authority to access information related to their duties, and the opportunity to make decisions related to their daily work. In the aspect of psychological empowerment of nurses, it was found that the sense of importance has a very important role, especially 
the feeling of having an influence on what happens in the hospital where the nurse works.

In the aspect of nurses' fatigue, it was found that the provision of a work environment that facilitates nurses to get opportunities and autonomy plays a high role in reducing nurses' fatigue levels. Hospital management can pay attention to the autonomy that nurses deserve. Hospitals also need to periodically evaluate the existing evaluation system in the hospital to make sure it is running properly and correctly. Management also needs to adjust nurses' workloads for reducing fatigues or exhaustions. By doing so, nurses can maintain their optimal performance. Research related to human resource development (HR) in healthcare professional during the COVID-19 pandemic is relatively rare. This is an opportunity to further deepen aspects related to this matter so that it can be developed into an opportunity to provide better services to patients and the community.

\section{References}

Beyer, W. H. (2017). Handbook of tables for probability and statistics (2nd ed.). CRC Press.

Butt, N., Saqib, S., Bashir, M., \& Habib, G. (2017). Impact of job autonomy, psychological empowerment and distributive justice on turnover intensions: Mediating role of organizational commitment. International Journal of Management \& Organizational Studies, 6(2), 58-74.

Catton, H. (2020). Global challenges in health and health care for nurses and midwives everywhere. International Nursing Review, 67(1), 4-6. https://doi.org/10.1111/inr.12578

Chen, Q., Liang, M., Li, Y., Guo, J., Fei, D., Wang, L., He, L., Sheng, C., Cai, Y., Li, X., Wang, J., \& Zhang, Z. (2020). Mental health care for medical staff in China during the COVID-19 outbreak. In The Lancet Psychiatry, 7(4), e15-e16. https://doi.org/10.1016/S22150366(20)30078-X

Demerouti, E., Bakker, A. B., Nachreiner, F., \& Schaufeli, W. B. (2000). A model of burnout and life satisfaction amongst nurses. Journal of Advanced Nursing, 32(2), 454-464. https:// doi.org/10.1046/j.1365-2648.2000.01496.x

Hair, J. F., Risher, J. J., Sarstedt, M., \& Ringle, C. M. (2019). When to use and how to report the results of PLS-SEM. In European Business Review, 31(1), 2-24. https://doi.org/10.1108/ EBR-11-2018-0203

Kang, L., Li, Y., Hu, S., Chen, M., Yang, C., Yang, B. X., Wang, Y., Hu, J., Lai, J., Ma, X., Chen, J., Guan, L., Wang, G., Ma, H., \& Liu, Z. (2020). The mental health of medical workers in Wuhan, China dealing with the 2019 novel coronavirus. In The Lancet Psychiatry, 7(3), e14. https://doi. org/10.1016/S2215-0366(20)30047-X

Kanten, S., \& Sadullah, O. (2012). An empirical research on relationship quality of work Life and work engagement. Procedia - Social and Behavioral Sciences, 62, 360-366. https://doi. org/10.1016/j.sbspro.2012.09.057

Khamisa, N., Peltzer, K., \& Oldenburg, B. (2013). Burnout in relation to specific contributing factors and health outcomes among nurses: A systematic review. In International Journal of Environmental Research and Public Health, 10(6), 2214-2240. https://doi.org/10.3390/ ijerph10062214

Krejcie, R. V., \& Morgan, D. W. (1970). Determining sample size for research activities. Educational and Psychological Measurement, 30(3), 607-610. https://doi. org/10.1177/001316447003000308

Liu, Z., Han, B., Jiang, R., Huang, Y., Ma, C., Wen, J., Zhang, T., Wang, Y., Chen, H., \& Ma, Y. (2020). Mental health status of doctors and nurses during COVID-19 epidemic in China. SSRN Electronic Journal. https://doi.org/10.2139/ ssrn.3551329

Maslach, C., \& Jackson, S. E. (1981). The measurement of experienced burnout. Journal of Organizational Behavior, 2(2), 99-113. https://doi.org/10.1002/job.4030020205

Maslach, C., \& Leiter, M. P. (2016). Understanding the burnout experience: Recent research and its implications for psychiatry. World Psychiatry, 15(2), 103-111. https://doi.org/10.1002/ wps.20311

Pan, Y., Guan, H., Zhou, S., Wang, Y., Li, Q., Zhu, T., Hu, Q., \& Xia, L. (2020). Initial CT findings and temporal changes in patients with the novel coronavirus pneumonia (2019-nCoV): a study of 63 patients in Wuhan, China. European Radiology, 30(6), 3306-3309. https://doi. org/10.1007/s00330-020-06731-x

Permarupan, P. Y., Mamun, A. Al, Samy, N. K., Saufi, R. A., \& Hayat, N. (2019). Effect of psychological empowerment on nurses burnout. The Open Nursing Journal, 13(1), 201-210. https://doi. org/10.2174/1874434601913010201

Permarupan, Y. Y., Mamun, A. Al, Samy, N. K., Saufi, R. A., \& Hayat, N. (2020). Predicting nurse's burnout through quality of work life and psychological empowerment: A study towards sustainable healthcare services in Malaysia. Sustainability (Switzerland), 12(1). https://doi. org/10.3390/su12010388

Ramdan, I. . M., \& Fadly, O. N. (2016). Analisis Faktor yang berhubungan dengan burnout pada perawat kesehatan jiwa. (Analysis of factors Associated with burnout in mental health nurses). Jurnal Keperawatan Padjadjaran, 4(2), 170-178. https://doi.org/10.24198/jkp. v4i2.240

Salimi, S., \& Saeidian, N. (2015). Relationship between quality of work life and psychological empowerment by employees' productivity (structural equations modeling). International Journal of Educational and Psychological Researches, 1(1), $10 . \quad$ https://doi. 
org/10.4103/2395-2296.147451

Sang Long, C., Owee Kowang, T., Ai Ping, T., \& Muthuveloo, R. (2014). Investigation on the impact of job stressors on nurses in Malaysia. Asian Social Science, 10(4), 67-77. https://doi. org/10.5539/ass.v10n4p67

Sarstedt, M., Ringle, C. M., \& Hair, J. F. (2017). Partial least squares structural equation modeling. In Handbook of Market Research. Springer International Publishing.

Schaufeli, W. B. (2006). The balance of give and take: Toward a social exchange model of burnout. Revue Internationale de Psychologie Sociale, 19(1), 87-131.

Sekaran, U., \& Bougie, R. (1993). Research methods for business: A skill building approach. Long Range Planning, 26(2), 136. https://doi. org/10.1016/0024-6301(93)90168-f

Spreitzer, G. M. (1995). Psychological, empowerment in the workplace: Dimensions, measurement And Validation. Academy of Management Journal, 38(5). https://doi.org/10.2307/256865

Spreitzer, G. (2008). Taking stock: A review of more than twenty years of research on empowerment at work. In The SAGE Handbook of Organizational Behavior: Volume I - Micro Approaches. SAGE Publications Ltd.

Wahyuningsih, I. S., Janitra, F. E., Hapsari, R., Sarinti, S., Mahfud, M., \& Wibisono, F. (2020). The nurses' experience during the caring of Coronavirus (COVID-19) Patients: A Descriptive Qualitative Study. Jurnal Keperawatan Padjadjaran, 8(3). https://doi. org/10.24198/jkp.v8i3.1559

Walton, R. E. (1975). The diffusion of new work structures: Explaining why success didn't take. Organizational Dynamics, 3(3), 3-22. https:// doi.org/10.1016/0090-2616(75)90027-3 